returned there, first as a demonstrator and then as a lecturer in physical chemistry. In 1945 he joined the British Iron and Steel Research Association and, continuing to work at Newcastle, carried out chemical and structural investigations on the iron-nitrogen, iron-carbon-nitrogen, and iron-carbon systems. This research was extended during 1947-49 at the Crystallographic Laboratory, Cavendish Laboratory, Cambridge, and included work on nitrogen martensite and on the tempering of nitrogen and carbon martensites. He is at present a lecturer in the Inorganic Chemistry Laboratories of King's College, Newcastle, and is working on the cobalt-carbon-nitrogen system and the ageing of nitrogen ferrites.

Dr. W. A. Wood

Dr. Wood joined the National Physical Laboratory, Teddington, in 1928 after graduating in physics from the University of Manchester. His first work was on the application of X-ray diffraction to the study of industrial materials, and led to early publications on the structure of magnet steels, electro-deposits and cold-worked metals. After taking his D.Sc. for work on the structural changes produced by the fatigue stressing of metals, he developed apparatus for precision measurements of the atomic spacings of metals under stress and obtained the first stressitrain curves for the atomic lattice of a metal. In 1947 he was appointed senior research fellow, with the status of associate professor, in the then newly established Metallurgy Research Department of the University of Melbourne, where he has directed the work of research students in metal physics and with them has been responsible in particular for new observations on the mechanisms by which metals become deformed at elevated temperatures.

\section{Hyman Goldsmith Memorial Award of the Bulletin of Atomic Scientists}

THE Hyman Goldsmith Memorial Award of the Bulletin of Atomic Scientists has been made to Dr. Walter Gellhorn, professor of law in Columbia University, for his book "Security, Loyalty, and Science" (Cornell University Press, 1950 ; see Nature, 168,$305 ;$ 1951). The Award is given annually in honour of one of the founders of the Bulletin, H. H. Goldsmith, who died in August 1949, and is for the article, book or pronouncement which, in the opinion of a special committee appointed by the Bulletin, is the best contribution to the clarification of the right relations between science and politics.

\section{Productivity in Industry}

IN replying to a debate in the House of Commons on the production efficiency of industry, on the adjournment on April 10, the Parliamentary Secretary to the Board of Trade, Mr. Henry Strauss, agreed with $\mathrm{Mr}$. H. A. Watkinson, who opened the debate, that the time for sending teams to the United States is coming to an end, and stated that very few are now being sent and none after June. The AngloAmerican Council on Productivity will come to an end when the work it is doing in collecting and transmitting information on the latest American techniques tapers off. The Government, said Mr. Strauss, is watching with interest the conversations in progress between the constituent bodies of the Council to determine whether any purely British body should be set up to take its place, but he would not agree that the new body should necessarily have a Minister as chairman or include members of the
House of Commons. The business of increasing production, he continued, is non-party and nonpolitical and, though the Government and Parliament can encourage it, it is primarily a task for industry.

\section{New Technical University at Veszprém, Hungary}

THE now Veszprém Technical University, which is the main centre in Hungary for training and research in the heavy chemical industry, has recently announced the completion of its third building. It is hoped that a five-story laboratory building will be completed in the autumn next, and the main university building, containing lecture rooms, a large congress hall and the university library, are scheduled to be ready next year. The University contains four faculties: industrial chemistry, mineral oil and coal, electro-chemistry and silicate industry ; for instructional purposes the University contains a small coking-plant, a pitch-distilling plant and an oil refinery. There are 520 students at present in residence; they study for four years, two years being devoted to general chemistry, and specialization beginning in the third year. Also at Veszprém are two research institutes, for heavy chemical industry and for mineral oil and natural gas, respectively. The former is housed temporarily in a wing of the University, but it is expected that its new building will be ready by next autumn; the institute is engaged on research into coke processes, the extraction of phenol from gas water, and on the production of low-price artificial fertilizers. The research institute for mineral oil and natural gas, which is situated near the University, has various departments, one of which, the motor research station, tests motor-fuel and lubricants under various conditions, including low temperatures.

\section{Dynamic Machine for Testing Roads}

A мовпl vibration machine for testing roads, invented at the Shell Laboratories in Amsterdam, was demonstrated to road engineers at the recent Ninth International Road Congress in Lisbon. The test is non-destructive in that samples are not taken from the road. Measurements are made of the velocity of propagation of vibrations produced in the road structure by the machine, and picked up by electromagnetic geophones placed at various distances from it. A frame carrying three shafts with eccentric masses generates a sinusoidal force giving an amplitude of loading of $300-2,000 \mathrm{kgm}$, at frequeneies within the range 5-60 c./s. The geophones are coupled to a low-frequency oscilloscope and an electronic voltmeter, the latter giving the amplitude of the vibration. The phase displacement of the vibration in the road surface is determined at various distances from the vibrator, and at various test frequencies, and the wave-length thus determined is plotted against frequency, from which the velocity of propagation is deduced. Velocities of propagation in each layer of a multi-layer road structure can be determined by measurements on the surface, and their elastic constants deduced, together with the rigidity of the construction. From the knowledge thus gained, it is hoped to develop a technique to determine whether the road has sufficient strength to meet the requirements of the traffic expected. So far, only one machine has been completed, and was used in tests at the Amsterdam International Airport, Schipol (see Van der Poel, C., Proc. 2nd International Conf. on Soil Mechanics, Rotterdam, 1948, 4, 157 ; J.App. Chem., 1, 281 (1951) ; and Electronic Measuring (published by 